RENATA POMPAS

MILÁN, ITALIA

RENATA.POMPAS@GMAIL.COM

\title{
Colours and Textile Design in Digital era
}

\author{
Colores y Diseño Textil en la era digital
}

\begin{abstract}
In this digital time everyone can plan a printing textile design importing each image through a scanner and repeating it several times. When a digital ink jet print transfers the design result on the fabric, the trick is done. In this way, it seems that a professional design project is unnecessary, because everyone believes to be a professional designer. On the contrary, professionalism in planning textile design is specific and unique in relation to every other visual approach (graphics, art, photo, etc.). This paper aims to prove it.
\end{abstract}

Keywords: colour, colour repeat pattern, digital planning, textile design.

Resumen. En esta época, basado en el uso de las herramientas digitales, cada individuo es capaz de crear un diseño para la impresión textil, a través del uso de imágenes tomadas con el escáner y repetidas varias veces. Cuando una impresora de inyección de tinta para el tejido transfiere el diseño sobre la tela, el truco ha tenido éxito. De esta manera, parece que no es necesario para hacer un diseño profesional, porque cada uno cree ser un diseñador profesional. Pero contrariamente a esa idea, el diseño de cualquier proyecto en la tela impresa es específico y único en comparación con todos los otros métodos visuales (diseño gráfico, arte, fotografía, etc.). Este documento pretende demostrarlo.

Palabras clave: color, diseño textil, planificación digital, patrón de repetición de color.

\section{INTRODUCTION}

Digital technology has deeply modified the entire textile production process, from the planning phase to production and distribution. In my courses I teach colour and planning of printed fabric, a sector in which Italy has achieved a leading position as far as quality, fancy, taste and refinement are concerned. In this sector, High Quality production has introduced digital technology in almost all phases, starting from stocking fabric to be printed in warehouses to engraving screen-printing and rotary printing, to the actual printing phase. High End, as people know, still prefers screen-printing, which makes it possible to achieve special effects like pigments and metallizations, and which is made even quicker and more precise by means of electronic printing. However, rotary printing, used for less prestigious production lines, is also very widespread. The real breakthrough of the printing project, however, is the constant technical evolution of ink jet digital printing, in which the traditional colouring agents are replaced by 8 colour cartridges, which make it possible to print even considerable amounts of fabric, with almost all types of chromatic ranges and pictorial effects, while avoiding, however, overlapping or any further treatments. The executive project, contained in a CD-ROM, is included in the ink jet machine and it is ready to be printed. 


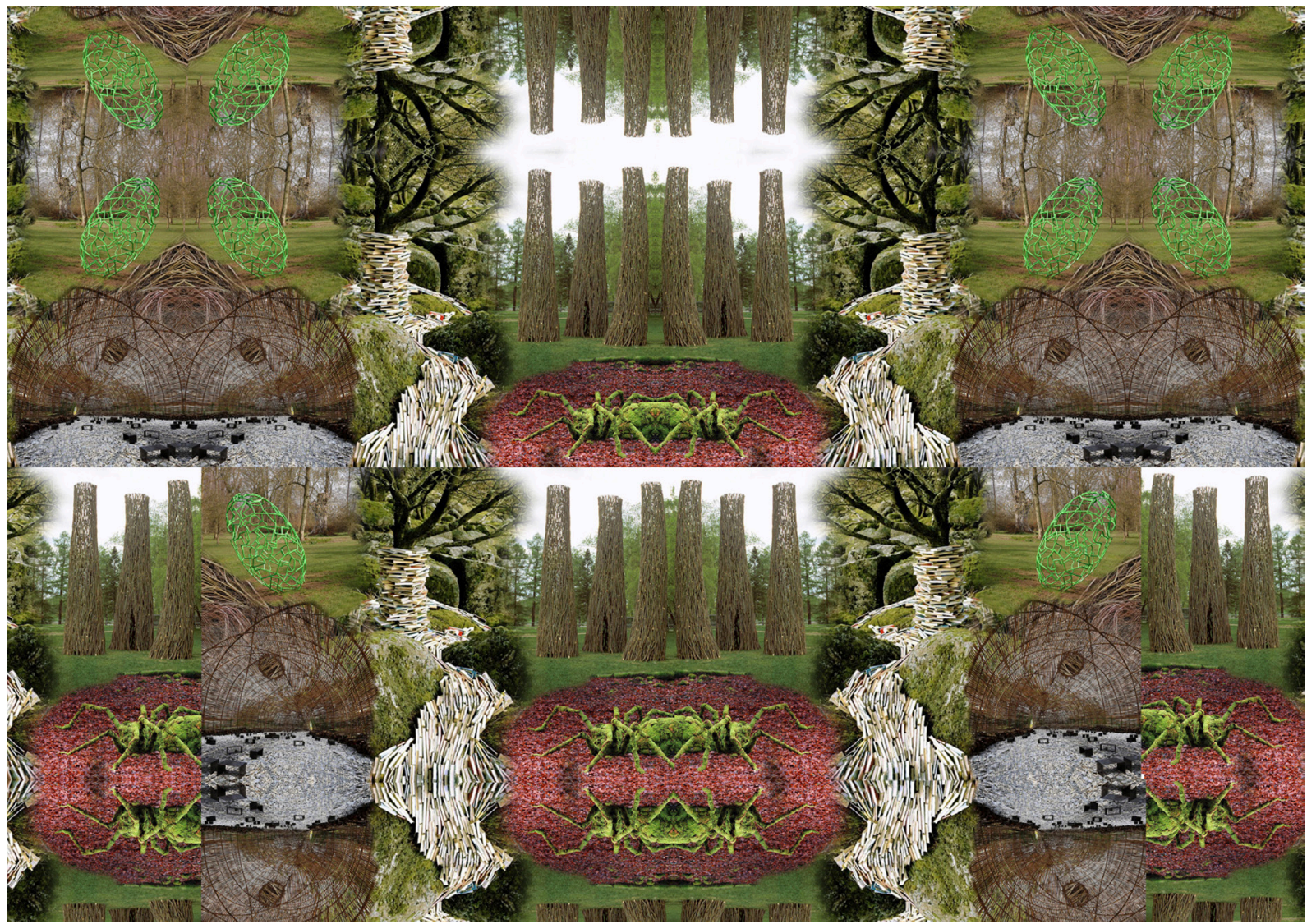

Figure 1. Moodboard inspiration: vegetal landscape. Project by Simona Musmeci.

\section{METHODOLOGY}

I analyse how the digital revolution has affected the planning of printed fabric, in the passage from traditional pictorial procedures to the use of digital images. Nowadays, it is possible to create a pattern to be printed by simply acquiring an image by means of a scanner, which can be modified at a later stage by means of virtual tools (ranging from brushes to aerographs), register it by modifying its proportion, preparing the colourways, choosing among millions of colours. In addition to this, technology enables operators to see the final result without needing to start the production process.

These facilitations, however, do not change the basic problem designers have to tackle, namely that printed textiles are peculiar visual planned actions, different from any other one.

My intention is to share the experience I have achieved in a long time of teaching, rewarded by the professional success of my students, which led me to devise a very simple didactic method to understand printed textile projects, a few examples of which will be reported below.

\section{To perceive}

In any visual planning operation, the meaning of an image stems from the choice of figurative elements, their mutual relations and their relations with the space in which they are contained (field). If you choose any 


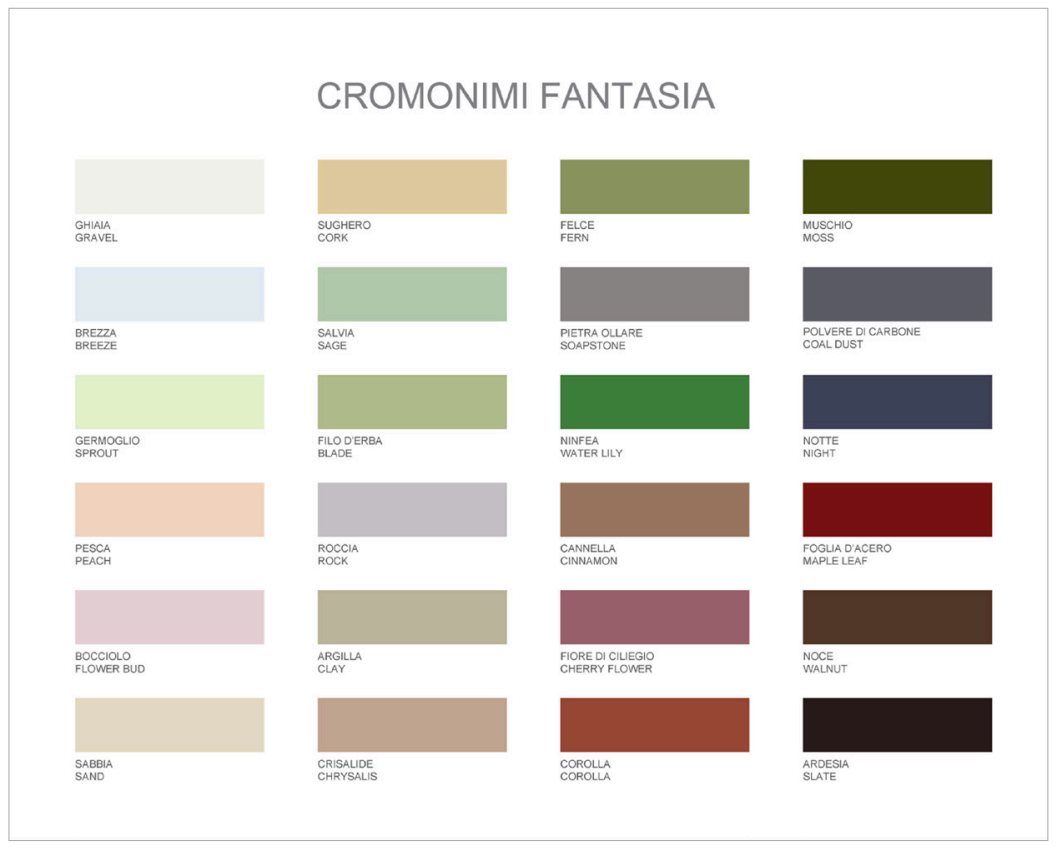

non-figurative and achromatic element, for instance a small black square, and place it on a white surface that contains it, this element will express its position with reference to the space margins. Its position makes it possible to perceive it as on the right side or on the left side or on top or at the bottom, even more so if it moves from the centre of the area where it is placed, an area which I will call the "field" (Marcolli, 1971). The position of this element in space also creates the impression that it is either stable or unstable, the former situation is suggested, for instance, by its being located in the centre of the diagonals of the field, its parallel sides being the margins. If we rotate the element in an asymmetrical way with reference to the sides of the areas in which it is contained, and move it away from the centre of the field, it creates an impression of instability and direction. If we evolve from this simple exercise on the element/field relation into the use of several elements of various sizes, the relation of reciprocity is added to the first one; this new relation takes place between the elements, depending on their sizes and positions. It is possible to suggest a direction of the movement, which can be interpreted from right to left or vice versa, or from top to bottom or vice versa. Or it is possible to suggest an aggregation movement towards the centre or a dispersion one towards the periphery. The presence of several elements facilitates abstract communication of shape and composition. Some of these perceptual phenomena were described by the Gestalt psychology, which investigated the cultural stereotypes that affect our vision and translated them into some of its statements. The theorists argue, among other things, that we organize our vision according to the laws of simplicity and economy, linking nearby virtual and similar visuals stimuli to virtual lines, and composing them into a comprehensible and memorable unit. The contemporary theorists D.A. Dondis and Wucius Wong, among others, have also profoundly studied these laws.
Figure 2. Color palette of vegetal landscape. Project by Simona Musmeci. 


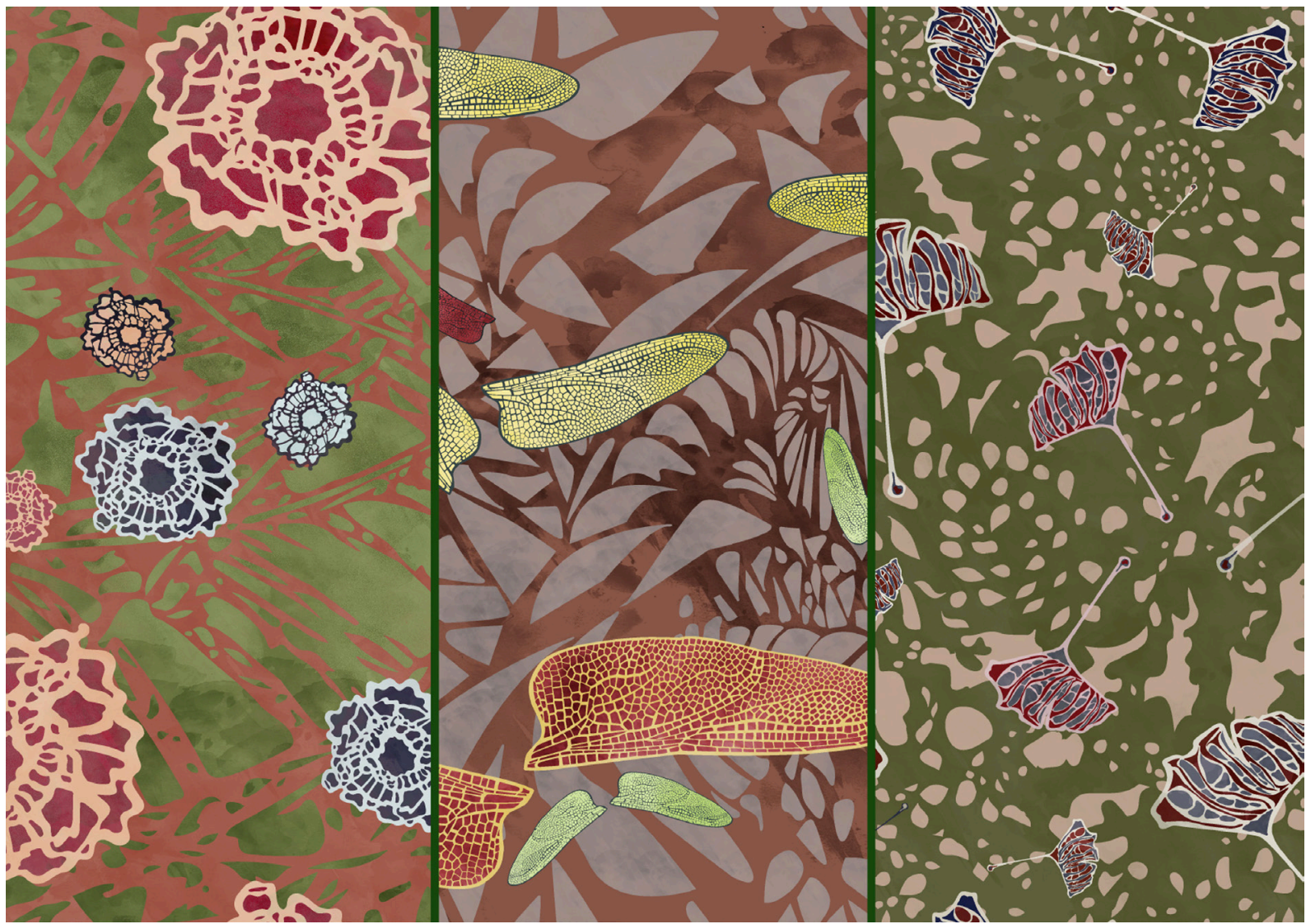

Figure 3. Composition with three projects for vegetal landscape.

\section{To organize}

I stated that the planning phase of printed fabric differs from any other type of visual planning. Indeed, in textile design, each single component is repeated a large number of time, or rather a virtually infinite one, as this scheme shows. The use of large textile repetition patterns was massified during the Arts \& Crafts period, mainly from the work of William Morris. This process, which is called all-over, deeply affects the overall sense of the composition, since it may modify the sense attributed to the basic module. In all-over reproductions, the margins of the field cease to exist, therefore the elements in the composition do not establish any relations with the space in which they are contained and lose the traditional right-left, top-bottom, large-small and direction references. I believe that this is a key point in the designing phase, especially now that everyone thinks s/he is able to make drawings for printing operations by working in a traditional way, that is by means of a wonderful project enclosed in a space, while the designer is not interested in its repetition. As a matter of fact, drawings in which the register is made at a later stage by a tracer are often carried out and bought. In this way, the designer loses full control of the composition and the meaning of his/her project.

I will explain also how colours work in the all-over process, in ways which are sometimes different and independent from those of the shape, thus making the management of results even more complex. 


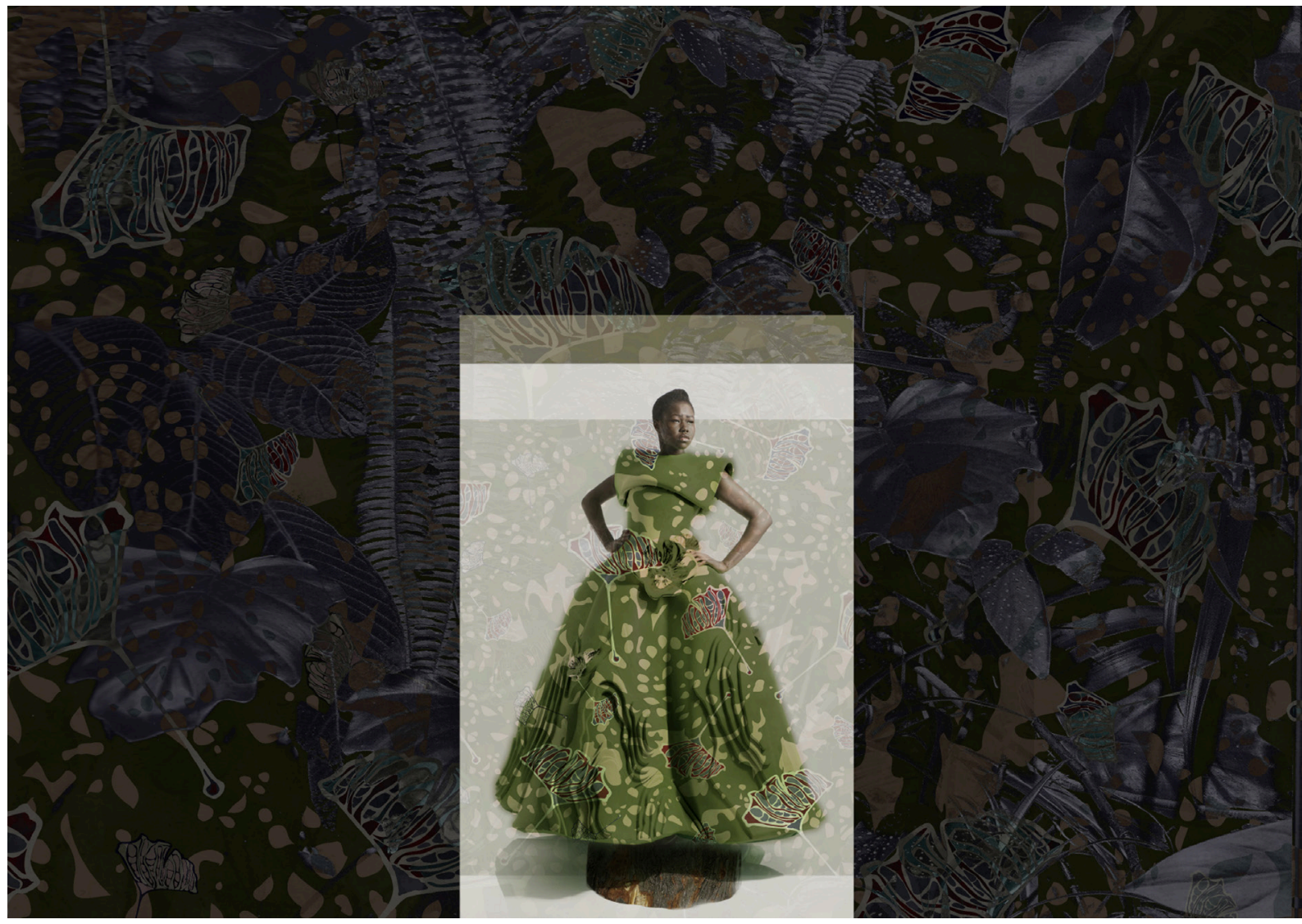

\section{Shape and all-over}

When a module in which an element placed within a field seems to move rightwards is reproduced in an all-over process, the direction disappears as you may see by comparing the module within the field and its multiplication. The curious thing in this is that by multiplying all the modules taken into consideration before, regardless of the position of the abstract element, they all seem to give rise to the same results that is to compose a regular and static texture. The same thing also happens when modules with an abstract element, which does not lose its space references, are reproduced several times. Since the design for printed fabric has no definite space/field, it loses all references of measurement, proportion and spatial collocation, therefore, in order to suggest them, it has to be resort to the reciprocal relations which are established between the elements and their positions.

At this point, it is of paramount importance that designs also take into consideration the elimination of the sides of the original module as a characteristic to strengthen, in order to avoid its repetition from becoming monotonous. In order to appreciate the unique specificity of textile design of having a virtually endless space/field requires some dynamic compositive solutions.
Figure 4. Presentation of Simona Musmeci's project for a dress.

\section{Colour and all-over}

This long foreword on shapes is fundamental in order to deal with the specificity of textile design, with reference to colours. Colours are the most 
important element in a textile design: the first pattern which is seen and for which a certain fabric is chosen and bought. Those who work in this sector know that an unattractive design with beautiful colours may be sold, whereas a beautiful design with unattractive colours may not. A good colour expert may determine the success of a whole collection. In the all-over method, colours interfere with shapes and their perception, mainly due to their attribute of brightness, which determines the visual resources of weight and movement. An achromatic composition of square elements which remain placed in a dynamic and varied way in the all-over system may be appreciated, or depreciated, by a wrong distribution of colours.

By "wrong" I mean a way of colouring which contradicts the original meaning of the module, where light colours are replaced by dark colours, for instance, modifying the whole perception of the all-over design. This creates different routes or which draws people's attention to some spots, thus unbalancing the visual concentration. A design devoid of visual foci, which forms a continuous texture, can modify the type of the composition depending on its colouring. In the relation between background colour and the colours of coloured figurative elements, it is possible to create lines aggregates, groups, textures or other types of compositions, on the basis of the chromatic qualities of hue, brightness and intensity, defined by Albert Henry Munsell (1905). This is why my students, after doing exercises in which they place shapes in the all-over space, practice placing colours in their mutual relations and with reference to the background colour.

\section{CONCLUSION}

Affirms P. Bourdieu that "style is a manner to represent expressing the manner to perceive the world and to think an age" (Bourdieu, 1979). I believe that not only did specific colours have - and still have - a meaning, but their "range quality" has also been decisive. By this term I mean not only the three perceptual attributes of colour (hue, lightness and saturation) but also surface finishing (matte, shiny, metallic, pearly, greyed, etc.) and the full palette in its chromatic significance. Today colour cards no longer have an intrinsic forecasting and orientation function, but have taken on the just as valid function of highlighting certain themes among the many that are present simultaneously on a market that is always more global, unstable and uncontrolled in its stylistic developments. The function that colours take on today is that of giving proposals visibility, strength, emotion and recognisability, separating them from the background noise made up of a messy accumulation of styles, hybrids, mixtures and positioning of visual relations, taking on an identity role between global and local markets. 


\section{Bibliography}

Bourdieu, P. (1979). La distinction-critique sociale due jugement. Paris: Editions de Minuit.

Marcolli, A. (1971). Teoria del campo. Corso di educazione alla visione. Florencia: Sansoni Editori.

Munsell, A. H. (1905). A Color Notation. Boston: Geo. H. Ellis Co.

Pompas, R. (1994). Textile Design. Ricerca-ElaborazioneProgetto. Milan: Hoepli.

Pompas, R. (1995). Una trama complessa. Risk, (Jan./Feb.).

Pompas, R. (1999). Progettare tessuti alla Naba. Jacquard, (39).

Pompas, R. (2000). Textile design training at the Nuova Accademia di Belle Arti in Milan. Textile Forum, (1).

Pompas, R. (2001). Che colore mi metto?. Nodus, XII.

Pompas, R. (2001). Fashion designers' trading desk at Ideacomo. Textile Forum, (1).

Pompas, R. (2005a). Italian Textile Trends. Texere News $\theta$ Info., (Jun.).

Pompas, R. (2005b). La moda e il consumo di colore: quale approccio?. In: S. Rizzo (2005). Colore e design tra comunicazione e produzione. Genova: De Ferrari.

Pompas, R. (2006a). Fashion Textile Design Corse in Milan. Texere News e Info., (Oct.).

Pompas, R. (2006b). I colori per la Primavera Estate 2007 a Milano Unica. Colore, (Apr./Jun.).

Pompas, R. (2007). Studiare Textile Design a Milano. Colore, (Oct./Dec.). 